\title{
COMPARATIVE STUDY OF DIFFERENT MAINTENANCE STRATEGIES
}

A characteristic feature of complex technical objects for special purposes is the presence in their composition of a large number (tens, hundreds of thousands) of various types component parts, which have different levels of reliability, different patterns of their wear and tear processes. This feature requires a more subtle approach to the organization and planning of maintenance in course of their operation.

The problem is that in the development of such facilities, all issues related to maintainability and maintenance should be addressed already at the early stages of facility design. If you do not provide in advance the necessary hardware and software for the built-in monitoring of technical condition (TC) of the object, do not develop and "build" the maintenance technology into the object, then it will not be possible to realize in the future a possible gain in the reliability of the object due to maintenance. Since all these issues must be resolved at the stage of object creation (when the object does not yet exist), mathematical models of the maintenance process are needed, with the help of which it would be possible to calculate the possible gain in the level of reliability the facility due to maintenance, to estimate the cost costs required for this. Then, on the basis of such calculations, make a decision on the need for maintenance for this type of objects and, if such a decision is made, develop the structure of the maintenance system, choose the most acceptable maintenance strategy, and determine its optimal parameters.

The article shows that the optimal parameters of various maintenance strategies significantly depend on both the reliability and cost structure of the facility and specified requirements for the facility's reliability $T_{0}^{\mathrm{TP}}$. The higher the specified value $T_{0}^{\mathrm{TP}}$, the more serviced items should be included in the optimal maintenance strategy.

It has also been proven that the effectiveness of various maintenance strategies depends significantly on the reliability and cost structure of object. If the distribution of cost restored (including serviced) elements is closely correlated with the distribution of their reliability indicators, difference in effectiveness of different maintenance strategies is reduced. This is clearly seen in the example of Test-2 object, for which the least reliable elements are also the most expensive.

Keywords: maintance strategy, components, reliability level, facility structure.

Introduction. Complex technical objects in modern society are extremely important. We are talking primarily about various radio-electronic systems for military and special purposes, radar stations, automated control systems (air traffic, energy facilities, etc.). The state's defense capacity, economic security, and the lives of hundreds and thousands of people depend on the level of reliability of such facilities.

Such objects belong to the class of recoverable objects of long-term repeated use. They are usually expensive and costly to operate. To ensure the required level of reliability during their operation, maintenance is usually carried out, the essence of which is timely preventive replacement of elements in a pre-failure state.

Analysis of recent research. The "surge" in number of theoretical works on the maintenance of complex systems falls on 70s of the last century, which can be explained by the mass production of complex radio-electronic equipment for military and special purposes at that time [1-4]. Currently, there is a decline in the number of scientific publications devoted to the maintenance of complex technical objects. One of reasons for this, in our opinion, is the sharp increase in the level of integration and reliability of components. Thanks to this, the developers of complex equipment were able to solve the issues of ensuring required level of reliability without significant maintenance costs (or without maintenance at all). However, the same reason (high integration and reliability of component parts) opened up the possibility of implementing more and more complex technology with new functions, which was impossible with the old element base. This again leads objectively to the 
problems of ensuring reliability and, therefore, question of the need for maintenance and the choice of optimal strategy for its implementation again becomes relevant.

Formulation of the problem. Unfortunately, the currently known mathematical models and methods for calculating the optimal parameters of MC processes are not very suitable for application to real technical objects. The main disadvantage of these models is that they either do not take into account the complex structure of an object at all, or it is possible to take into account only some of the simplest structures [5, 6]. In [7], a comparative analysis of the problems arising in solving the problems of maintenance "by resource" and "by state" is made. An overview of the latest work in the field of maintenance and repair of complex systems for that period is given. In [8], a theoretical generalization of the known mathematical models of MC processes is made. However, these models do not allow constructing methods suitable for practical use on their basis.

In our opinion, the situation is even worse with mathematical models of MC processes "by state". Only a small number of scientific works are devoted to this area of research [9-11].

Thus, the work solves the urgent scientific problem of developing methods and tools (software) to determine the optimal parameters of the maintenance strategy "by state" of complex technical objects.

Main part. The complexity of maintenance processes and the variety of factors influencing them significantly complicate the choice between different maintenance strategies. For an objective comparison of the advantages and disadvantages of various maintenance strategies, it is necessary to ensure the approximate equality (sameness) of the conditions in which they are applied.

When comparing different maintenance strategies, we will be guided by the following principles:

- it is possible to compare different maintenance strategies only by the results of their application to the same object;

- test objects (on which the comparison of maintenance strategies is made) should be comparable in terms of the structure time and cost costs for maintenance and maintenance;

- indicators of the quality maintenance process (objective functions), according to which the comparison of various maintenance strategies is made, should be evaluated at the same intervals of the object's operation and with the same parameters of modeling process (if the comparison of maintenance strategies is made based on the simulation results);

- characteristics of maintenance process obtained with the optimal parameters of maintenance strategies should be compared, that is, the potential capabilities of various maintenance strategies should be compared.

In this study, 4 test objects are used that differ in their reliability and structural characteristics. This, among other things, makes it possible to check and simultaneously demonstrate the "performance" of developed methods for determining the optimal parameters of various maintenance strategies for different initial data.

To ensure the comparability of the structure of time and cost costs for maintenance and current repairs, the characteristics of maintainability and cost that are the same for all elements and objects were set:

- average recovery time of an element $\tau_{\mathrm{B} i}=1 \mathrm{~h}$;

- average duration of maintenance $\tau_{\text {то } i}=1 \mathrm{~h}$;

- item cost $C_{i}=10$ c. u.;

- cost of operation current repair (replacement) of the element $C_{\mathrm{tp} i}=1 \mathrm{c}$. u.;

- cost of the maintenance operation of element $C_{\mathrm{ro} i}=1 \mathrm{c}$. u.;

STD characteristics for test objects are set as follows:

- duration of diagnostics at $\mathrm{MC} \tau_{\text {д }}=0.5 \mathrm{~h}$;

- cost of the diagnostic operation at $\mathrm{MC} C_{д}=1$ c.u. 
The same for all test objects are also set the indicators depending on the purpose of object - the specific cost losses incurred by the external system (in which this object is used) in the object failure state $c_{\text {отк }}=10 \mathrm{c.u} . / \mathrm{h}$, and in the MC state $c_{\text {то }}=1 \mathrm{c} . \mathrm{u} . / \mathrm{h}$.

For all test objects, using the developed methods, optimal parameters for three maintenance strategies were determined. For brevity, as before, we will call them: "MC by state", "adaptive MC" and "MC by resource".

All calculations were made for the duration of operation $T_{\ni}=20$ years with continuous operation of the facilities.

The optimal parameters of various maintenance strategies were determined under the idealized assumption of the existence for test objects of measurable determining parameters for the least reliable elements $E_{\text {то }}$ related to the set of recoverable elements $E_{\mathrm{в}}$. The subsets of potentially serviced items were specified in such a way that they included all the least reliable items. There are no elements in test objects, reliability of which would be lower than the reliability of any elements $E_{\text {то }}\left(E_{\text {то }} \subset E_{\mathrm{B}}\right.$ ). Obviously, under this condition, with the optimal parameters of maintenance strategies, maximum, potentially possible efficiency of maintenance is provided, which is most likely unattainable in practice.

Table 1 - 4 presents the final results of calculating optimal parameters of various maintenance strategies. In fig. 1 - 4 shows the graphs of the mean time $T_{0}$ between failures and the unit cost of operation $c_{\text {уд }}$ from the number of serviced elements, obtained with the optimal parameters of the corresponding maintenance strategies.

Table 1

Comparative evaluation of indicators, $T_{0}, c_{\text {уд }}$ and $K_{\text {ти }}$ for object Test-1 with different maintenance strategies

\begin{tabular}{|c|c|c|c|c|c|}
\hline \multicolumn{2}{|c|}{$\begin{array}{c}\text { Maintenance } \\
\text { strategy }\end{array}$} & $\begin{array}{l}\text { Maintenance } \\
\text { condition }\end{array}$ & $\begin{array}{c}\text { Adaptive } \\
\text { maintenance }\end{array}$ & $\begin{array}{l}\text { Maintenance } \\
\text { by resource }\end{array}$ & $\begin{array}{c}\text { Without } \\
\text { maintenance }\end{array}$ \\
\hline \multirow{4}{*}{ 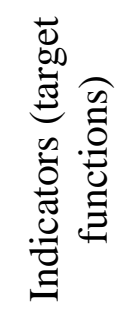 } & $T_{0}, \mathrm{~h}$ & 1660 & 1662 & 1609 & 1236 \\
\hline & $c_{\text {уд }}$, c.u. $/ \mathrm{h}$ & 0,01461 & 0,01408 & 0,01695 & 0,02187 \\
\hline & $K_{\text {ти }}$ & 0,99851 & 0,99877 & 0,99689 & 0,99919 \\
\hline & $\varepsilon$ & 0,180 & 0,179 & 0,184 & 0,085 \\
\hline \multicolumn{2}{|c|}{$\begin{array}{c}\text { Optimal } \\
\text { maintenance } \\
\text { strategy parameters }( \\
\left.T_{0}^{\mathrm{Tp}}=1500 \mathrm{~h}\right)\end{array}$} & $\begin{array}{l}\left|E_{\mathrm{To}}^{*}\right|=3 \\
U_{\mathrm{To}}^{*}=\{0,5 ; 0,4 ; 0,5\} \\
T_{\mathrm{r}}^{*}=1200 \mathrm{~h}\end{array}$ & $\begin{array}{l}\left|E_{\mathrm{To}}^{*}\right|=3 \\
U_{\mathrm{To}}^{*}=\{0,5 ; 0,4 ; 0,5\} \\
\gamma^{*}=0,45 ; \beta=0,5\end{array}$ & $\begin{array}{l}N_{\mathrm{To}}^{*}=1 \\
\left|E_{\mathrm{To} 1}^{*}\right|=3 \\
T_{\mathrm{To}}^{*}=1400 \mathrm{~h}\end{array}$ & - \\
\hline
\end{tabular}




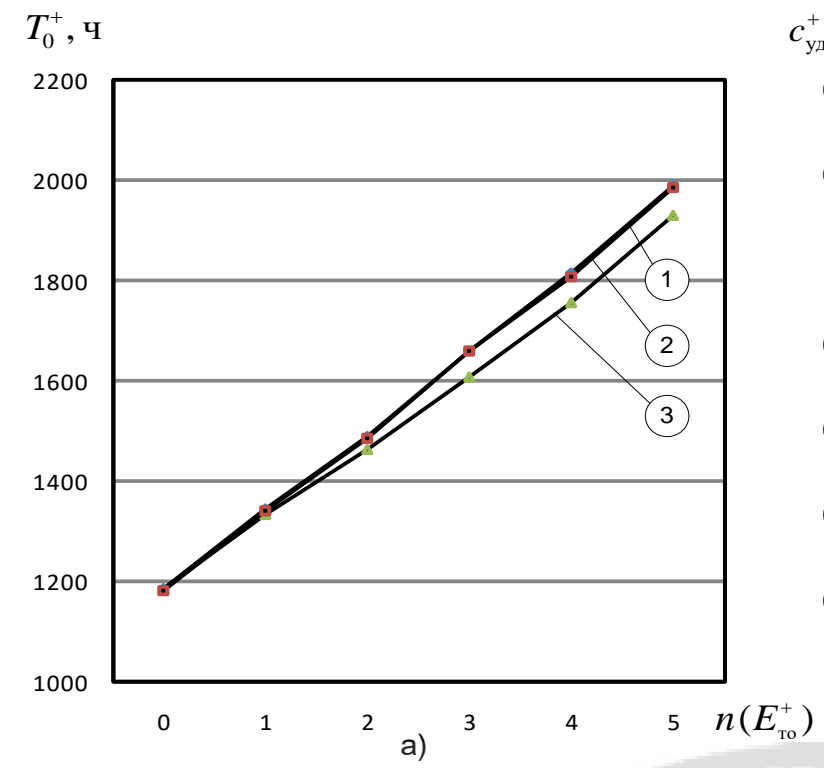

$c_{\text {уд }}^{+}$, y.e./ч

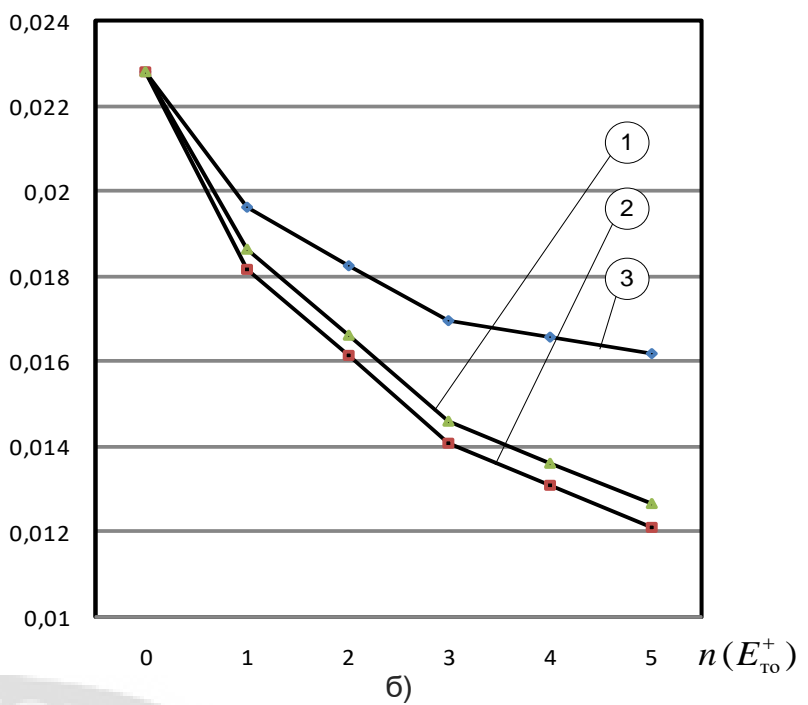

Figure 1 - Graphs dependence indicators $T_{0}^{+}$and $c_{\mathrm{yд}}^{+}$on the number of serviced elements for various maintenance strategies (object Test-1):

1 - maintenance by condition; 2 - adaptive maintenance; 3 - maintenance by resource

Table 2

Comparative assessment of indicators $T_{0}, c_{\text {уд }}$ and $K_{\text {ти }}$ for the object Test-2 with different maintenance strategies

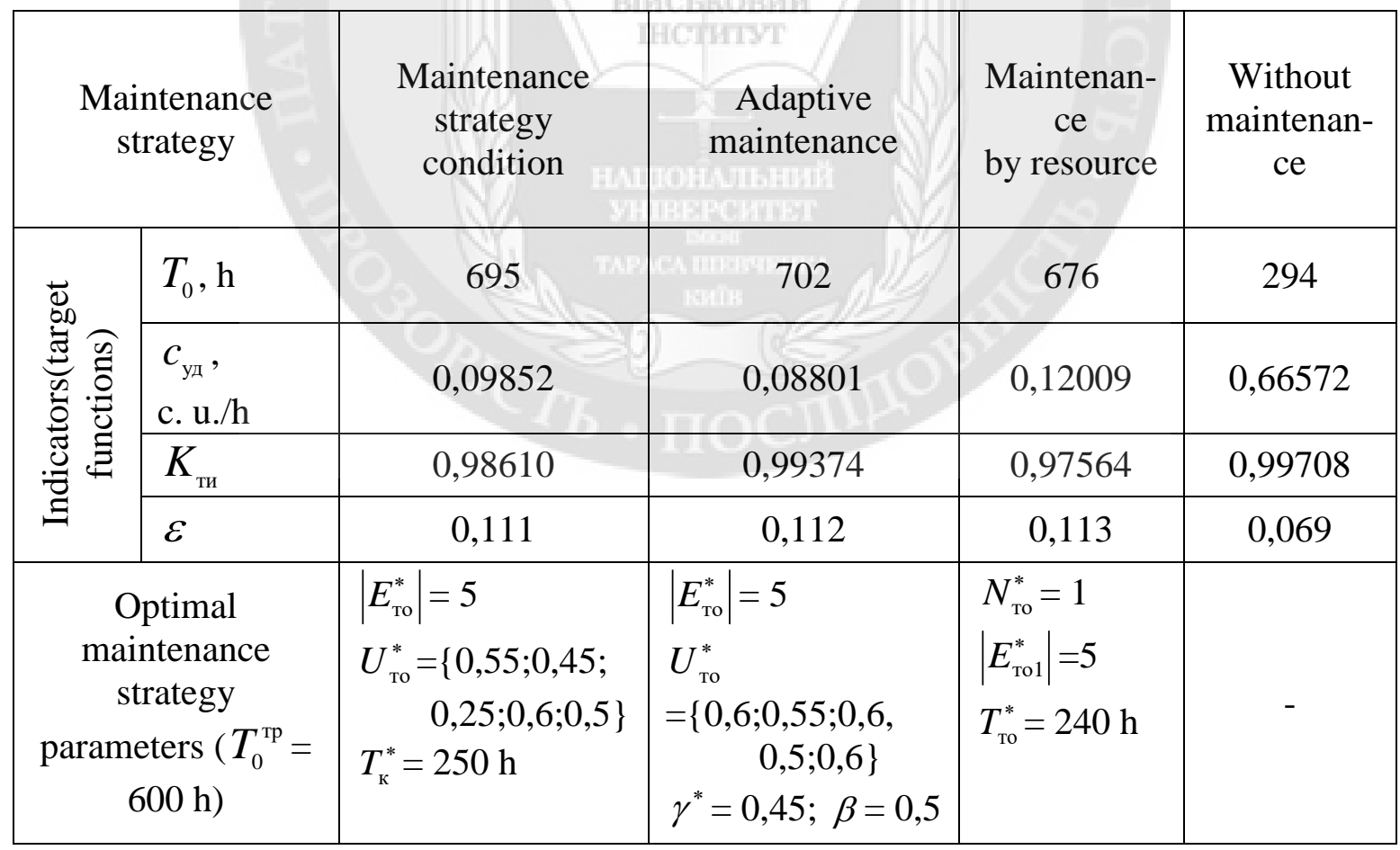




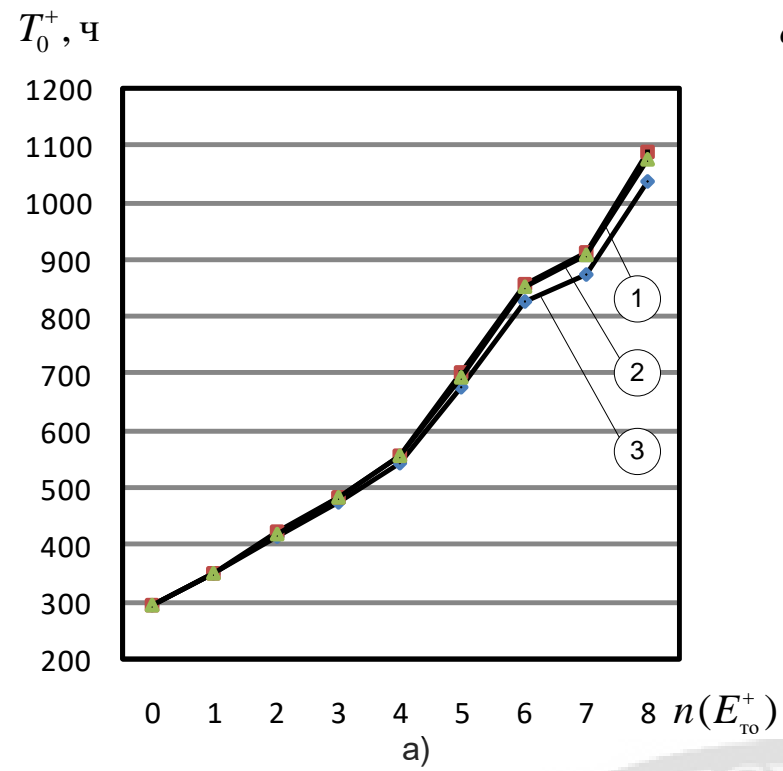

$c_{\mathrm{yд}}^{+}$, y.e./ч

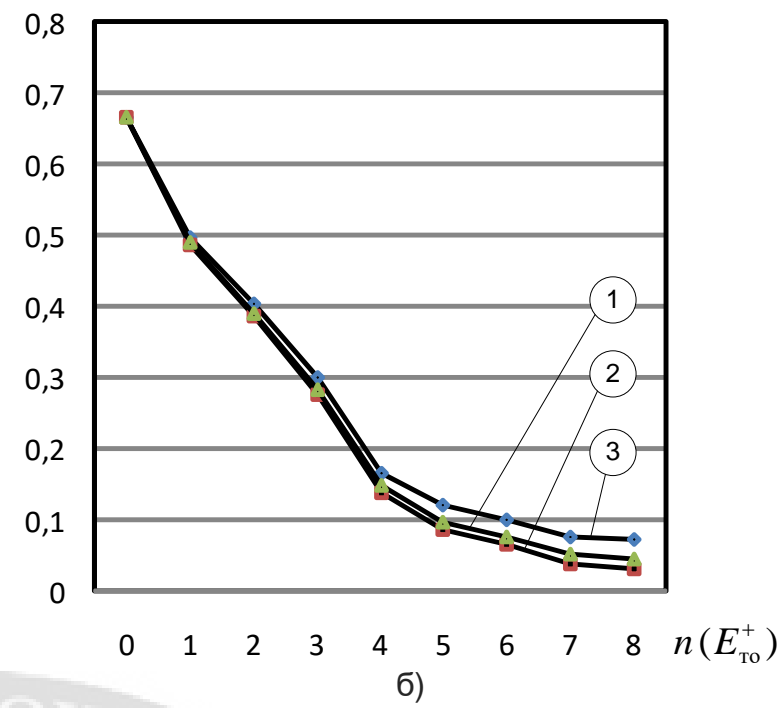

Figure 2-Graphs of dependence indicators $T_{0}^{+}$and $c_{\mathrm{yд}}^{+}$on number of serviced elements for various maintenance strategies (object Test-2):

1 - maintenance by condition; 2 - adaptive maintenance; 3 - maintenance by resource

Table 2

Comparative assessment of indicators $T_{0}, c_{\text {уд }}$ and $K_{\text {ти }}$ for object Test-3 with different maintenance strategies

\begin{tabular}{|c|c|c|c|c|c|}
\hline \multicolumn{2}{|c|}{$\begin{array}{c}\text { Maintenance } \\
\text { strategy }\end{array}$} & $\begin{array}{l}\text { Maintenance } \\
\text { condition }\end{array}$ & $\begin{array}{l}\text { Adaptive } \\
\text { maintenance }\end{array}$ & $\begin{array}{c}\text { Maintenan- } \\
\text { ce } \\
\text { by resource }\end{array}$ & $\begin{array}{l}\text { Without } \\
\text { maintenan- } \\
\text { ce }\end{array}$ \\
\hline \multirow{4}{*}{ 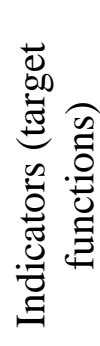 } & $T_{0}, \mathrm{~h}$ & 15194 & 15136 & 15009 & 9458 \\
\hline & $\begin{array}{l}c_{\text {уд }}, \\
\text { c.u../h }\end{array}$ & 0,00154 & 0,00151 & 0,00169 & 0,00232 \\
\hline & $K_{\text {ти }}$ & 0,99982 & 0,99984 & 0,99967 & 0,99978 \\
\hline & $\varepsilon$ & 0,487 & 0,448 & 0,493 & 0,367 \\
\hline \multicolumn{2}{|c|}{$\begin{array}{c}\text { Optimal } \\
\text { maintenance } \\
\text { strategy } \\
\text { parameters } \\
\left(T_{0}^{\text {тp }}=15000 \mathrm{~h}\right)\end{array}$} & $\begin{array}{l}\left|E_{\mathrm{To}}^{*}\right|=3 \\
U_{\text {то }}^{*}=\{0,5 ; 0,5 ; \\
0,5\} \\
T_{\mathrm{K}}^{*}=10500 \mathrm{~h}\end{array}$ & $\begin{array}{l}\left|E_{\text {то }}^{*}\right|=3 \\
U_{\text {то }}^{*} \\
=\{0,7 ; 0,6 ; 0,5\} \\
\gamma^{*}=0,4 ; \beta=0,5\end{array}$ & $\begin{array}{l}N_{\mathrm{to}}^{*}=1 \\
\left|E_{\mathrm{To} 1}^{*}\right|=4 \\
T_{\mathrm{To}}^{*}=16000 \\
\mathrm{~h}\end{array}$ & - \\
\hline
\end{tabular}




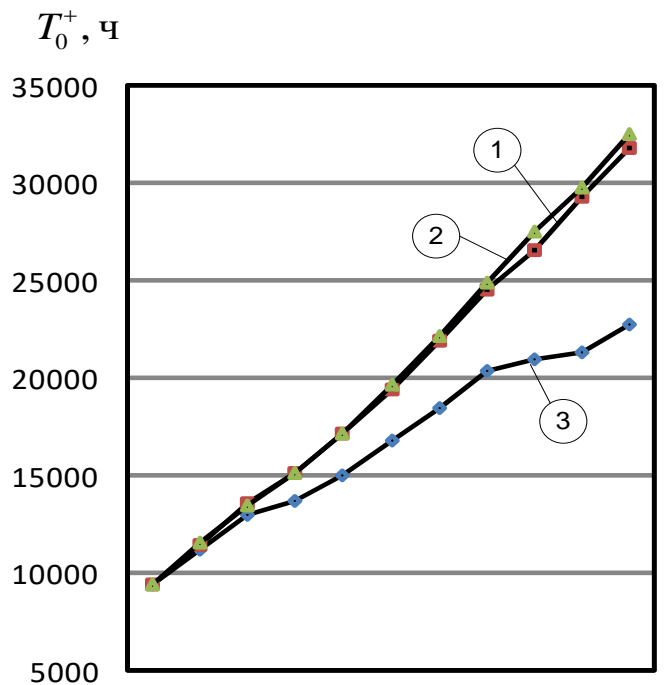

$\begin{array}{lllllllllllll}0 & 1 & 2 & 3 & 4 & 5 & 6 & 7 & 8 & 9 & 10 & n\left(E_{\text {то }}^{+}\right)\end{array}$

a) $c_{\text {уд }}^{+}$, у.e./ч

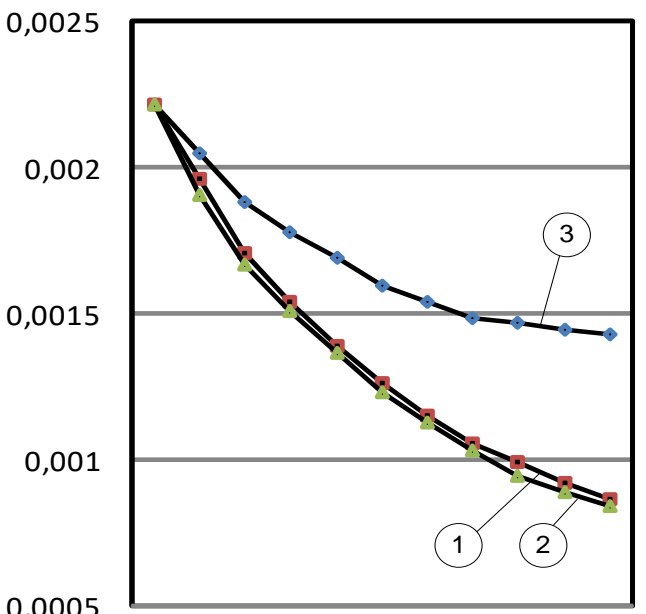

$\begin{array}{llllllllllll}0 & 1 & 2 & 3 & 4 & 5 & 6 & 7 & 8 & 9 & 10 & n\left(E_{\mathrm{To}}^{+}\right)\end{array}$

б)

Figure 3 - Graphs of dependence indicators $T_{0}^{+}$and $c_{\text {уд }}^{+}$on number of serviced elements for various maintenance strategies (object Test-3):

1 - maintenance by condition; 2 - adaptive maintenance; 3 - maintenance by resource

Table 3

Comparative evaluation of indicators $T_{0}, c_{\text {уд }}$ and $K_{\text {ти }}$ for object Test-4 with different maintenance strategies

\begin{tabular}{|c|c|c|c|c|c|}
\hline \multicolumn{2}{|c|}{$\begin{array}{c}\text { Maintenance } \\
\text { strategy }\end{array}$} & $\begin{array}{c}\text { Maintenance } \\
\text { condition }\end{array}$ & $\begin{array}{l}\text { Adaptive } \\
\text { maintenance }\end{array}$ & $\begin{array}{l}\text { Maintenance } \\
\text { by resource }\end{array}$ & $\begin{array}{c}\text { Without } \\
\text { maintenance }\end{array}$ \\
\hline \multirow{4}{*}{ 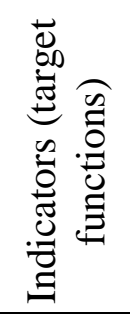 } & $T_{0}, \mathrm{~h}$ & 6575 & 5566 & 4879 & 914 \\
\hline & $c_{\text {уд }}$, c.u./h & 0,00668 & 0,00637 & 0,01180 & 0,02296 \\
\hline & $K_{\text {ти }}$ & 0,99736 & 0,99776 & 0,99323 & 0,99890 \\
\hline & $\varepsilon$ & 0,268 & 0,209 & 0,311 & 0,113 \\
\hline \multicolumn{2}{|c|}{$\begin{array}{c}\text { Optimal } \\
\text { maintenance } \\
\text { strategy parameters } \\
\left(T_{0}^{\text {Tp }}=5000 \mathrm{~h}\right)\end{array}$} & 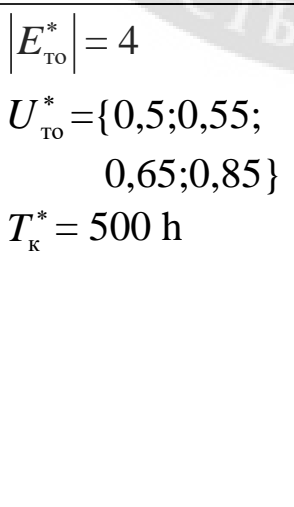 & $\begin{array}{l}\left|E_{\mathrm{то}}^{*}\right|=3 \\
U_{\text {то }}^{*}=\{0,55 ; 0,55 ; \\
\quad 0,55\} \\
\gamma^{*}=0,5 ; \beta=0,5\end{array}$ & $\begin{array}{l}N_{\mathrm{To}}^{*}=3 \\
\left|E_{\mathrm{To} 1}^{*}\right|=3 \\
T_{\text {то } 1}^{*}=600 \mathrm{~h} \\
\mid E_{\mathrm{To} 2}^{*}=3 \\
T_{\text {то } 2}^{*}=6000 \mathrm{~h} \\
\left|E_{\mathrm{ro} 3}^{*}\right|=4 \\
T_{\text {то } 3}^{*}=22000 \mathrm{~h}\end{array}$ & - \\
\hline
\end{tabular}



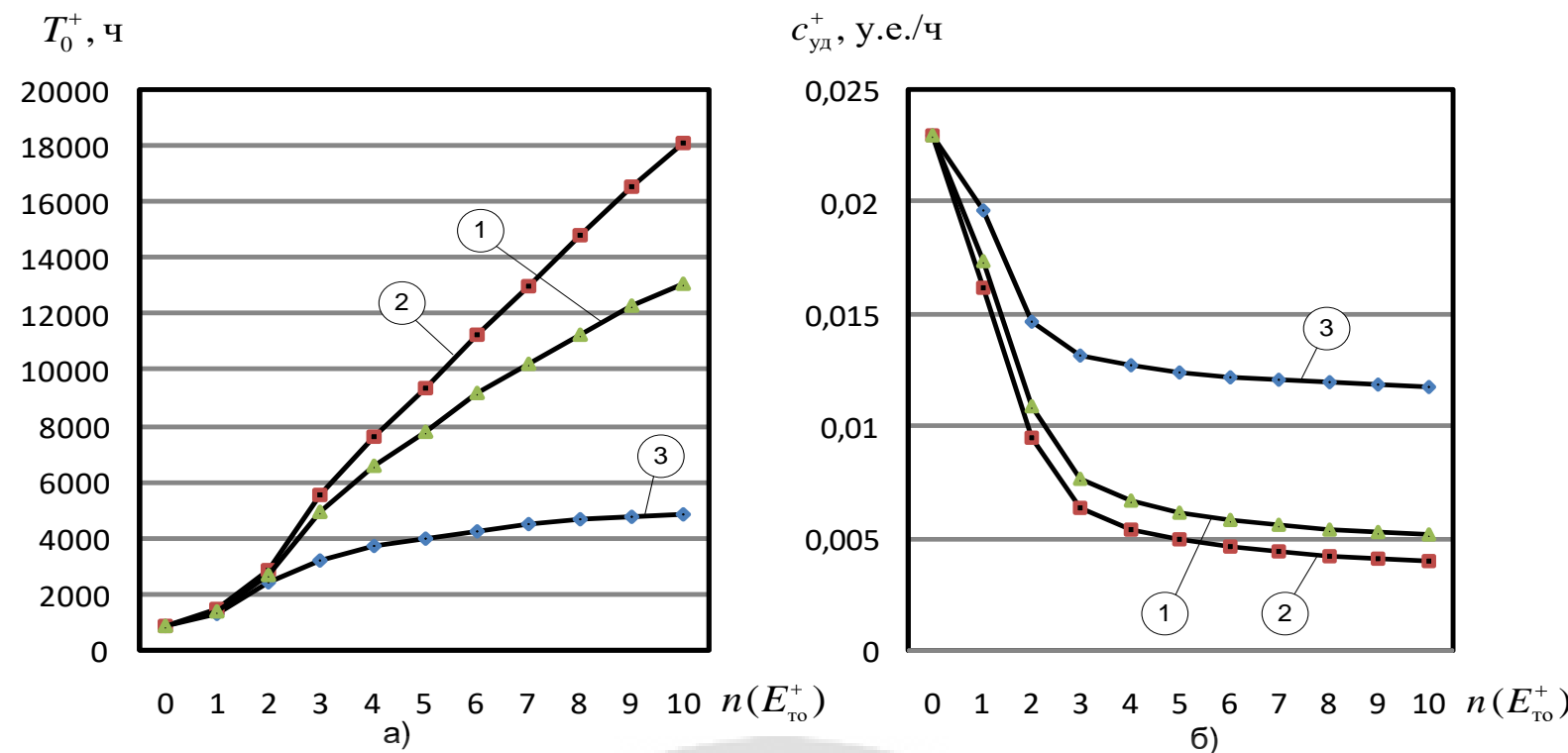

Figure 4 - Graphs of dependence indicators $T_{0}^{+}$and $c_{\text {уд }}^{+}$on number of serviced elements for various maintenance strategies (object Test-4):

1 - maintenance by condition; 2 - adaptive maintenance; 3 - maintenance by resource

For Test- 4 object specified requirement $T_{0}^{\mathrm{Tp}}=5000 \mathrm{~h}$ with the optimal "maintenance by resource" strategy is not ensured (despite the fact that all potentially serviced elements have been used).

The "adaptive maintenance" strategy has not been studied separately. The adaptive MC parameter $\beta$ (exponential smoothing constant) was set equal to 0.5 for all test objects. This corresponds to a neutral situation, when the "weight" of the initial data on reliability indicators of elements (priori information) and data on the actual measured values of determining parameters (a posteriori information) is approximately the same.

Without delving into the study strategy of "adaptive maintenance", it can be assumed that adaptive maintenance is more profitable in the case of unreliable initial information about the indicators of reliability elements of object. We will check this assumption as follows.

Let us calculate indicators $T_{0}$ and $c_{\text {уд }}$ for test objects in the case when mean time to failure of all recoverable elements $T_{\mathrm{cp} i}$ is 2 times less than the indicators for which the parameters of the optimal maintenance strategy were calculated.

Obviously, indicators $T_{0}^{\prime}$ and $c_{\text {уд }}^{\prime}$ obtained in this case should be worse in comparison with the indicators $T_{0}$ and $c_{\text {уд }}$ obtained with the initial values. Table 3 and 4 show the values coefficients of relative losses in the level of reliability $\delta_{T_{0}}$ and in unit cost of operation $\delta_{C_{\text {уд }}}$, which were determined by formulas:

$$
\delta_{T_{0}}=\frac{T_{0}-T_{0}^{\prime}}{T_{0}} \cdot 100 ; \delta_{C_{\mathrm{yд}}}=\frac{c_{\mathrm{yд}}^{\prime}-c_{\mathrm{yд}}}{c_{\text {уд }}} \cdot 100,
$$

where $T_{0}\left(c_{\text {yд }}\right)$ - is mean time between failures (unit cost of operation) obtained at optimal parameters $T_{\mathrm{cp} i}$, provided that the indicators correspond to the values specified for test objects in test examples; 
$T_{0}^{\prime}\left(c_{\mathrm{yд}}^{\prime}\right)$ - same indicators obtained with optimal parameters, but under the condition that the indicators $T_{\mathrm{cp} i}$ in initial data are reduced by 2 times.

Based on the results obtained, the following conclusions can be drawn:

1. The best in terms of mean time between failures $T_{0}$ and unit cost of operation $c_{\text {уд }}$ is the "adaptive maintenance" strategy. This is followed by the "maintenance by condition" strategy. The worst is "MC by resource" strategy. The maintenance strategy is considered the best if the function graph $T_{0}^{+}$is located higher (for function $c_{\text {уд }}^{+}-$lower) in relation to corresponding graph for the compared strategy. The maintenance strategy, best in terms $T_{0}^{+}$of performance, is usually the best in terms $c_{\text {уд }}^{+}$of performance, and vice versa.

2. The strategies "maintenance by condition" and "adaptive maintenance" are very similar in terms of the obtained indicators. This is due to their common nature - during maintenance, information about the actual current state of the object is used.

3. The effectiveness of various maintenance strategies depends significantly on the reliability and cost structure of object. If distribution of the cost restored (including serviced) elements is closely correlated with the distribution of their reliability indicators, difference in effectiveness of different maintenance strategies is reduced. This is clearly seen in the example of Test- 2 object, for which the least reliable elements are also the most expensive.

4. The optimal parameters of various maintenance strategies substantially depend on both the reliability and cost structure of the facility and the specified requirement for the facility's reliability $T_{0}^{\text {тр }}$. The higher the specified value $T_{0}^{\text {тр }}$, more serviced items should be included in the optimal maintenance strategy.

\section{REFERENCES:}

1. Forecasting to reliability complex object radio-electronic texnology and optimization parameter their technical usage with use the simulation statistical models: [monography] in English / Sergey Lenkov, Konstantin Borjak, Gennady Banzak, Vadim Braun, ets.; under edition S.V. Lenkov. - Odessa: Publishing house "VMV", 2014. - $252 \mathrm{p}$.

2. Jason Brown, Lucas Mol On the roots of all-terminal reliability polynomials / Discrete Mathematics, Volume 340, Issue6, June 2017, pages 1287-1299.

3. Lirong Cui, Yan Li, Jingyuan Shen, Cong Lin Reliability for discrete state systems with cyclic missions periods / Applied Mathematical Modtlling, Volumt 40, Issues 23-24, December 2016, Pages 10783$10799 /$

4. Iris Tien, Armen Der Kiureghian Algorithms for Bayesian network modeling and reliability assessment of infrastructure systems / Reability Engineering \& System Safety, Volume 156, December 2016, Pages 134-147.

5. Volokh O.P. Methods of substantiation rational values of periodicity technical maintenance of machines engineering armament during operation // Collection of scientific works of MIKNU named after T. Shevchenko. Issue 2. K .: MIKNU, 2005. - Pp. 29-32.

6. Boryak K.F. Reliability model of a complex restored object of radio-electronic equipment // Collection of scientific works of MIKNU named after T. Shevchenko. - K .: 2009. - № 21. - Pp. 33-41.

7. Reliability and efficiency in technology. Directory. T.2. Mathematical methods in the theory of reliability and efficiency / Ed. B.V. Gnedenko. M .: Mechanical engineering, 1988 . - 280 p.

8. Computational methods of research and design of complex systems. Mikhalevich V.S., Volkovich V.L. - M .: The science, 1982. - 286 p.

9. Brown V.O., Boryak K.F., Lantvoit O.B., Tsytsarev V.N. Modeling of maintenance processes complex reconstructed objects of radio-electronic equipment // Bulletin of the Engineering Academy of Ukraine. - K., 2008. - №1. - Pp. 47 - 52.

10. Boryak K.F. Pre-service to process of technical service foldable radioelectronic equipment for additional and statistical statistical model // Bulletin of Engineering Academy of Ukraine. - K., 2008. - No. 2. - Pp. 85 - 91.

11. Banzak G.V. Database on the reliability of complex objects of radio-electronic equipment / G.V. 
Banzak, K.F.Boryak, V.N. Tsytsarev // Collection of scientific works of MIKNU named after T. Shevchenko. - 2010. - No. 27. - Pp.89 - 97.

\section{к.пед.н., доц. Толок І.В., к.т.н. Банзак Г.В., к.т.н. Лснков Є.С., Возікова Л.М. ПОРІВНЯЛЬНЕ ДОСЛІДЖЕННЯ РІЗНИХ СТРАТЕГІЙ ТЕХНІЧНОГО ОБСЛУГОВУВАННЯ}

Характерною особливістю складних технічних об'єктів спеціального призначення є наявність в їх складі великої кількості (десятки, сотні тисяч) різнотипних комплектуючих елементів, які мають різний рівень надійності, різні закономірності процесів їх зносу і старіння. Ця особливість вимагає більш тонкого підходу до організації $і$ планування ТО в процесі їх експлуатації.

Проблема полягає в тому, що при розробці таких об'єктів всі питання, пов'язані $з$ ремонтопридатністю і технічним обслуговуванням повинні вирішуватися вже на ранніх етапах проектування об'єкта. Якщо не передбачити заздалегідь необхідні апаратні і програмні засоби вбудованого контролю технічного стану (ТC) об'єкта, щц не розробити і не "вбудувати" в об'єкт технологію проведення ТО, то реалізувати в майбутньому можсливий виграш в безвідмовності об'єкта за рахунок проведення ТО не вдасться. Оскільки всі ці питання повинні вирішуватися на етапі створення об'єкта (коли об'єкта ще немас), необхідні математичні моделі процесу ТО, за допомогою яких можна було б прорахувати можливий виграш в рівні безвідмовності об'єкта за рахунок проведення ТО, оцінити необхідні для цього вартісні витрати. Потім на підставі таких розрахунків прийняти рішення про необхідність проведення ТО для даного типу об'єктів $i$, якщи таке рішення прийнято, розробити структуру системи ТО, вибрати найбільш прийнятну стратегію ТО, визначити ї̈ оптимальні параметри.

У статті показано, цчо оптимальні параметри різних стратегій ТО істотно залежать як від надійно-вартісної структури об'єкта, так і від заданого вимоги до рівня безвідмовності об'єкта. Чим більще задане значення, тим більща кількість обслуговуваних елементів мас включатися в оптимальну стратегію ТО.

Також доведено, щио ефективність різних стратегій ТО істотно залежить від надійновартісної структури об'скта. Якщо розподіл вартості елементів, щзо відновлюються (в тому числі $і$ обслуговуються) близько корелюсться 3 розподілом їх показників безвідмовності, відмінність в ефективності різних стратегій ТО скорочується. Це добре видно на прикладі об'єкта Test-2, для якого найменш надійні елементи одночасно с і найбільш дорогими.

Ключові слова: стратегія технічного обслуговування, комплектуючі елементи, рівень надійності, структура об'єкта. 